\title{
THE POSITION OF A COMPANY IN THE PRODUCTION CHAIN OF THE PULP AND PAPER INDUSTRY FOCUSING ON THE ADOPTION OF ECO-INNOVATION STRATEGIES*
}

\author{
Received on: $12 / 04 / 2015$ \\ Approved on: 22/04/2017 \\ Marlete Beatriz Maçaneiro ${ }^{1}$ \\ Sieglinde Kindl da Cunha ${ }^{2}$ \\ João Carlos da Cunha ${ }^{3}$ \\ Marcos Roberto Kühl ${ }^{4}$ \\ Pedro José Steiner Neto ${ }^{5}$
}

\begin{abstract}
This study sought to gauge to what extent companies in the production chain focus on the relationship between contextual factors and the definition of eco-innovation strategies. The methodology is based on a quantitative approach using a survey in 117 companies. The results show that, in general, the companies in the sample the correlation with proactive innovation strategies was especially strengthened for those at the beginning of the production chain, with an increase in the mean for this group. This result is not in keeping with the literature when it comes to the sample data. In the literature, companies that operate in the latter stages of the production chain ought to have a greater impact at the environmental actions, as they have more direct contact with consumers of the end product. This improved performance for companies at the beginning of the production chain could be explained by the fact that these are the most polluting companies and have become the focus of environmental legislation.
\end{abstract}

Keywords: eco-innovation strategies, proactive strategy, reactive strategy, production chain, paper and cellulose sector.

\footnotetext{
* Agradecimento à Fundação Araucária de Apoio ao Desenvolvimento Científico e Tecnológico do Estado do Paraná pelo auxilio financeiro à execução da pesquisa.

$1 \mathrm{PhD}$ in Administration from Federal University of Paraná and Professor of Postgraduate Program in Administration at State University Midwest UNICENTRO, Guarapuava, Paraná, Brazil. E-mail: marlete.beatriz@yahoo.com.br

$3 \mathrm{PhD}$ in Economic Sciences from State University of Campinas - UNICAMP and Professor of Master's and PhD Programs in Administration - PMDA and the Postgraduate Program in Environmental Management - PGADM at Positivo University, Curitiba, Paraná, Brazil. E-mail: skcunha21@gmail.com $3 \mathrm{PhD}$ in Administration from University of São Paulo - FEA / USP and Consultant of Academic Ventures and the Higher Institute of Administration and Technology - ISAT. E-mail: jccunhaisat@gmail.com

$4 \mathrm{PhD}$ in Administration from Federal University of Paraná - UFPR, Professor of the Department of Accounting and the Postgraduate Program in Administration at State University Midwest-UNICENTRO, Guarapuava, Paraná, Brazil. E-mail: mkuhl@unicentro.br

$5 \mathrm{PhD}$ in Administration from University of São Paulo - FEA/USP, Scientific Coordinator of Research Center at Positivo University and Full Professor at Positivo University. E-mail: pedrosteiner@up.edu.br
} 


\section{INTRODUCTION}

The current level of global competition requires companies to seek new ways to maintain their competitiveness, being innovation considered a factor of competitive gains and an essential asset in the strategic agenda of organizations. Together with innovation, environmental resources management, through the concepts of sustainability, becomes more and more important for organizations in this context, since it can be translated into competitive advantage related to social legitimacy.

Therefore, environmental concerns and innovative solutions have been the subject of discussions in the recent decades in many sectors, such as the academic community, government policies and civil society organizations, as well as been attracting the interest of the business sector. That is due to the fact that the competitive setting of organizations has been changing because of the necessary search for sustainability, and they are obliged to change, from polluters to environmentally correct companies.

Eco-innovation is encouraged by a number of factors, including government regulations and subsidies, business opportunities for clean production and companies adopting an environmental ethic in response to public pressure. Aspects concerning eco-innovation have yet to be made known as they are still in the early phase of study and broader managerial issues regarding their implementation remain, as is the case with any context of an innovation system. Therefore, this study is based on the following research question: does the company's position in the production chain affect the relationship between contextual factors and the design of eco-innovation strategies?

The general aim of this study was to gauge to what extent the position of a company in the production chain of the sector in question leads the company to focus on the relationship between contextual factors and how they define eco-innovation strategies. More specifically, the intention was to map internal and external organizational factors that affect eco-innovation management, evaluating how this relationship changes as a result of where companies are located in the production chain. In this sense, the study is an empirical analysis of one of the propositions raised by Maçaneiro and Cunha (2014). Furthermore, the study is part of a larger study that sought to analyze within the Brazilian paper and cellulose industry the various aspects of the relationship between contextual factors and the adoption of eco-innovation strategies.

Companies from the cellulose, paper and paper products sector in Brazil were selected because their operations involve the use of natural resources and they are viewed as having a high potential for pollution in the eyes of the law that created the National Policy for the Environment (BRASIL, 1981). Moreover, this sector has been shown to be innovative, according to data from the Industrial Study of Technological Innovation (PINTEC), conducted by the Brazilian Institute of Geography and Statistics (IBGE) (2011), in which $82.6 \%$ of the companies in question implemented innovations in products and/or processes and/or organizations and/or marketing.

In recent times, sectors such as paper and cellulose have been under great pressure, by several stakeholder groups, to adhere to sustainability. This is due to the fact that these industry sectors are considered as potentially polluting and extractive of raw material from the natural environment, which makes it an important object of study in this subject, besides its economic relevance for the development of the country. But specifically for the purposes of the present study, it is a sector that has the characteristic of a production chain that most of the time is not made up of only one company. In other words, throughout the production cycle, different companies will work on different phases of production. There are, for instance, companies that only produce cellulose paste from planted forests, and there are others that acquire the cellulose paste and turn it into rough paper (SOUZA, 2004). 
This study contributes knowledge to the field of eco-innovation strategies through the definition of its constructs and the tests of the hypothesis. The work is original in that it is a study that was especially conceived and applied empirically, providing information on eco-innovation management, conductors and effects, enabling in-depth analyses, which are considered gaps in the literature. Therefore, this study contributes to the field in terms of the existing theory and the management of eco-innovation in organizations. It can serve as a guide for the innovative focus of environmental management in industries in the sector in question and other sectors, and can also aid further research in the field.

The following section contains a review of the literature that helped define the hypothesis for the study. This is followed by the methodological procedures and the composition of the constructs and a presentation of the characterization of the sample. The next section contains the analyses and tests of the hypothesis, and the work is brought to a close by the final considerations.

\section{THEORETICAL FRAMEWORK AND DEFINITION OF THE HYPOTHESIS}

The study of technological change or radical innovation is anchored in the dynamic evolutionary perspective, with authors Christopher Freeman, Richard Nelson, Sidney Winter and Giovanni Dosi as the forerunners. The Evolutionary Economic Theory was influenced by the writings of Joseph Alois Schumpeter, regarding the innovation process, being translated into a basis for research in the context of innovation systems (NELSON; WINTER, 2005). To Schumpeter (1982), the economic environment is characterized by relatively long periods of stability, marked by discontinuous and revolutionary changes. In this context, only innovative companies will survive, through the development of radical innovations or through the imitation of revolutionary products or services.

Therefore, innovations are crucial for organizations to have the capacity to remain competitive in the markets in which they operate and achieve economic sustainability. The terms sustainability or sustainable development "[...] are the most appropriate terms given their breadth, origin, and consistent inclusion of a company's financial success. And, of course, financial success is an indispensable element of a company sustainability initiative [...]." (BLACKBURN, 2008, p. 6-7).

It is in this context that eco-innovation is included, where the choice of adequate technologies and inherent processes covers a range of aspects related to environmental management. This involves a number of agents spurring development in countries and regions. The development of capabilities for eco-innovation management is conducted using a number of instruments such as public policies, a regulatory framework, financial mechanisms, public awareness, the participation of the people involved and other interested parties and the choice of technology (MAÇANEIRO; CUNHA; BALBINOT, 2013)

Eco-innovation is defined as the production, application or exploitation of a good, service, production process, organizational or managerial structure or business method that is new to the company or users. Its purpose during its lifecycle is to reduce environmental risks, pollution and the negative impact that stems from the use of resources in comparison with any corresponding alternatives (ARUNDEL; KEMP, 2009; KEMP; FOXON, 2007; RENNINGS, 1998). Therefore, eco-innovation strategies will be considered as one of the essential constructs of this study, composed of dependent variables that are adopted in different contexts and by different agents, generating reactive and proactive strategies.

Companies with reactive strategies do not view environmental management as a priority, and only invest in it to comply with the law. In this case, environmental regulations are merely seen 
as an institutional restriction, not as an opportunity to improve managerial practices. Furthermore, the involvement of the upper management is sporadic, in that environmental actions are confined to the areas of the company that cause pollution (BARBIERI, 2011; BUYSSE; VERBEKE, 2003).

"Firms with a reactive strategy attach high importance to government regulation, but only in a static sense, as an almost mechanistic and daily routine-driven response to new regulatory requirements." (BUYSSE; VERBEKE, 2003, p. 460). The strategy of pollution control is less efficient and reflects a reactive and selective approach to environmental issues, basically with end-of-pipe technologies. "Emissions and effluents are trapped, stored, treated, and disposed of using pollution-control equipment [...]" (HART, 1995, p. 992). However, these are expensive and normally unproductive processes because they only reduce the impacts at the end of the process. Firms " $[. .$.$] centralize their attention on the negative effects of their products and productive$ processes with isolated solutions. [...] They look forward to controlling pollution without altering, in a significant way, the processes and products which produced it [...]" (BARBIERI, 2011, p. 107).

Proactive strategies are necessary actions that are taken voluntarily to achieve a greater reduction in environmental impact and create a competitive advantage from the use of eco-innovative technologies. Furthermore, companies use changing regulations as a reference for the future allocation of resources and to create green competencies as a source of competitive advantage (BUYSSE; VERBEKE, 2003; HART, 1995; SHARMA, 2000; SHARMA; PABLO; VREDENBURG, 1999).

They are supported by the senior management of the organization and are defined as "pollution prevention" or "voluntarist" environmental strategies, which require the acquisition and installation of new technology, involving continuous learning, developing competitive organizational abilities and managing the total quality of the organization. This type of strategy has been looked at from a competitive perspective and the term is used to describe voluntary and innovative pollution prevention activities (MENGUC; AUH; OZANNE, 2010).

For an organization to decide between reactive and proactive strategies, a number of factors are involved, and these can affect the formulation of the type of strategy that will be chosen. In this study, these factors will be regarded as independent variable constructs, which affect eco-innovation strategies. It is important to highlight that these factors should be managed jointly and interactively, considering whether they should be viewed as an obstacle or as an opportunity to adopt environmentally adequate practices and technologies.

Some of the factors involved are external, including environmental regulations, which can be used by companies as a guide to environmental innovations, improving the productivity of the organization and making it more competitive (ANSANELLI, 2003; ASHFORD, 2000; PORTER; VAN DER LINDE, 1995). But companies do not always view the situation strategically, and view it as increasing the cost of remaining in business. Regulation instruments are those defined as legal standards for environmental performance, such as those of command and control. There are also the economic instruments, which are those which affect costs and consumption, as well as self-regulation by companies or industry sectors (SCHMIDHEINY, 1992). More specifically, the actions of the government regarding environmental issues are structured in several ways, such as the command and control regulations, incentives and subsidies (KANERVA; ARUNDEL; KEMP, 2009).

In addition to regulations, other external factors can affect eco-innovation strategies and, consequently, the environmental performance of organizations. Some have to do with government incentives, which can be considered in terms of: economic, of support to the incorporation of innovative technology in organizations; stimuli/constraints of private appropriation of the benefits of innovating; measures to support technological innovation related to the development, diffusion and efficient use of new technologies; support incentives (CASSIOLATO; LASTRES, 
2000; DOSI, 1988). More specifically, in Brazil, the governmental programs to support innovation are: subsidized resources (non-refundable); traditional financing instruments, but with special terms and rates, below those practiced in the financial market (refundable resources); government support for the use of risk capital; and tax exemption (FINEP, 2016). Companies also have support from international financing institutions.

Another external factor that influence eco-innovation strategies are the "reputation effects", which impact on the organization's image. Miles and Covin (2000) mention that a company's reputation translates into the perceptions of the most relevant stakeholders, such as: owners; local to international society and community, including current and future generations; customers; employees; suppliers and strategic partners; government agencies; banks and other creditors; and NGOs. More specifically, Carrillo-Hermosilla, Gonzalez and Könnölä (2009) highlight that the main external factors that can have influence on "reputation effect" issues are: information and relationship with the supply chain and other participants such as final consumers and public customers; environmental performance of competitors to maintain competitiveness; relationship with business associations and with NGOs that are sources of direct and indirect pressure on the development and adoption of eco-innovation; social awareness, since civil society can influence the adoption of environmental measures.

The internal factors that impact eco-innovation management include the support of strategic managers, which can play a critical role concerning the values of the organization regarding environmental issues. This can facilitate the implementation of a proactive strategy at the corporate level (MENGUC; AUH; OZANNE, 2010). “[...] Leaderships which are subject to an external context of greater pressure, demands and opportunities in relation to environmental issues tend to more often conceive that the environment plays a highly relevant role in the company's business." (SOUZA, 2004, p. 251). In this sense, key behaviors by top managers include aspects such as: "[...] communicating and addressing critical environmental issues; initiating environmental programs and policies; rewarding employees for environmental improvements; and contributing organizational resources to environmental initiatives." (MENGC; AUH; OZANNE, 2010, p. 281)

Other factors are highlighted in the literature, such as specific technological competencies for solving problems and absorbing the necessary changes, and environmental formalization (LUSTOSA, 2011; YOUNG; PODCAMENI; MAC-KNIGHT; OLIVEIRA, 2009). Technological competence is one of the factors that establish the bases for the adoption of a proactive environmental strategy. This is because it enables high organizational capabilities, such as learning, continuous innovation and experimentation (MENGUC; AUH; OZANNE, 2010). These competencies are related to physical resources and stock of human capital to develop eco-innovation; installation and adaptation conditions for the adoption of new clean technologies; ability to engage in collaborative and cause-andeffect information flows, with the creation of strategic relationships and alliances; improvement in the technological competency with the increase in knowledge and information and improving the competence basis of the company (CARRILLO-HERMOSILLA; GONZALEZ; KÖNNÖL̈̈, 2009). Technological competence also concerns the absorptive capacity of a company, which is a result of its innovation through investments in R\&D (COHEN; LEVINTHAL, 1990).

Environmental formalization is related to internal organizational structures directed to the adoption of organizational innovations for supporting eco-innovation, including: environmental mission and long-term goals statements for the reduction of emissions, consumption and for the environmental improvement of products; product life cycle analysis; environmental audits; the principles of ecodesign; and the implementation of environmental management systems. (KEMP; ARUNDEL, 1998; CARRILLO-HERMOSILLA; GONZALEZ; KÖNNÖLÄ, 2009). Also important is the inclu- 
sion of specific functions, activities, authority and responsibilities regarding environmental issues, which can provide the dissemination of ideas among members at all levels of the organization, turning them into a formal company's commitment (DONAIRE, 2007). Therefore, the contextual factors included in the analyses of this study have to do with: 1) environmental regulation; 2) the use of environmental incentives and incentives for innovation; 3) effect on reputation, which can impact the image of the organization; 4) support from the upper management regarding environmental issues; 5) the technological competence of the company; and 6) the degree of formalization of environmental management in the corporate structure. These factors can affect the formulation and type of strategy adopted by organizations and are the most frequently cited in the literature.

In this context of adopting eco-innovation strategies, the position of a company in the production chain can also impact to what extent it takes environmentally friendly actions. In the production chain of the pulp, paper and paper products sector, different companies work integrating stages of the production cycle, such as forestry, pulp, paper and paper goods production companies (SOUZA, 2004).

According to Carrillo-Hermosilla, Gonzalez, and Könnölä (2009), companies that operate in the latter stages of the production process are more likely to bow to pressure from environmentally aware consumers. Companies that are under pressure from such consumers give serious consideration to their social legitimacy and reputation when deciding on strategy (MENGUC; AUH; OZANNE, 2010). In this sense, the position in the production chain can reflect on the relationship between the "effect on reputation" factor and the adoption of eco-innovation strategies.

Moreover, authors such as Buysse and Verbeke (2003) note that these companies tend to have greater environmental formalization in their structure than other companies in their sector. To these authors, the transition to a more proactive management of the environment by conscious consumers is especially important in industries that have close contacts with consumers. Therefore, position in the production chain is also relevant in relation to the "environmental formalization" factor.

According to Souza (2004), these aspects have been identified in the cellulose, paper and paper products sector as opportunities for innovation are more commonly found in companies at the end of the production chain: the companies that produce paper artifacts. For this reason, innovation can lead to the development of more environmentally friendly solutions in a company's business. Therefore, position in the production chain can reflect on the relationship with the "technological competence" factor.

These issues and the seventh proposition of the study conducted by Maçaneiro and Cunha (2014), led to "position in the production chain" being defined as a moderating construct, with this being analyzed in the relationship between external and internal factors and the adoption of proactive and reactive eco-innovation strategies. Therefore, the hypothesis of the study is that the relationship between internal and external contextual factors in the adoption of eco-innovation strategies differs positively when the company operates at the end of the production chain.

In the next section, the methodology will be presented, along with the definition of the variables of the constructs and the composition of the theoretical model, based on the theoretical frame previously presented. 


\section{METHODOLOGY AND COMPOSITION OF THE CON- STRUCTS AND THE THEORETICAL MODEL OF THE STUDY}

The methodology is based on a quantitative approach using a survey. The study included 117 companies in the cellulose, paper and paper products sector from all over Brazil, and the data were collected through a computerized questionnaire that was forwarded using the Qualtrics ${ }^{\circledR}$ system. The questionnaire was tested for content validity by three specialist professors and was pre-tested with three managers in charge of environmental management at companies in the sector and two university professors in the field of strategy and sustainability.

The population of the study included 672 companies nationwide. After their e-mails and telephone numbers were obtained, they were contacted initially by e-mail and given an explanation of the purpose of the study and how to handle the questionnaire. Further contact was made with the people in charge of environmental management at the companies by telephone.

Of the companies that were contacted, 135 accessed the Qualtrics ${ }^{\circledR}$ page to answer the questionnaire, but only 97 answered every question and identified the company. A further 20 companies did not identify themselves, but provided full answers and data. Eighteen companies that began to answer the questionnaire but did not complete it, not even to respond to the variables, were excluded from the analysis. Therefore, the total sample was made up of 117 companies. In this sense, the sample was defined as non-probabilistic (not random). Participation was voluntary, in that certain people were invited to answer the questionnaire, but could decide whether or not to accept (COOPER; SCHINDLER, 2011).

Prior to the data analysis, the data were validated and cleansed to eliminate possible flaws due to errors during the answering of the questionnaire. The data were also checked for answers left blank and outliers. In this sense, each variable was analyzed using a box plot graph and no outliers were found among the 117 responses, and nor were there any missing values, since the electronic system that was used does not allow a respondent to leave a question unanswered.

The data analysis was based on inferential statistics through the Pearson correlation coefficient to test the hypothesis, and the $t$ test for independent samples to evaluate the statistical significance of the difference between the means of the groups. The representativeness of the sample was checked using the chi-square goodness of fit test, Cronbach's alpha to check the internal consistency of the scales of the constructs and graphical analyses.

These analyses were conducted from the hypothesis introduced in the previous section and through the constructs of: 1) environmental regulation; 2) use of environmental incentives and incentives for innovation; 3) effect on reputation; 4) support from upper management; 5) technological competence; 6) environmental formalization; 7) eco-innovation strategies; and 8) position in the production chain. These constructs were defined in operational terms, as presented below, with the variables constructed based on the literature.

The "environmental regulation" construct was measured using the four variables shown in Table 1, on a balanced five-point scale with a neutral position. The mean of the first two variables composed the regulation construct from the viewpoint of cost/threat, and the mean of the other two represented regulation viewed as opportunity. 
Table 1: Variables employed to measure the environmental regulation construct.

\begin{tabular}{|c|c|c|}
\hline \multicolumn{2}{|c|}{$\begin{array}{l}\text { Constructs/ } \\
\text { Variable }\end{array}$} & $\begin{array}{l}\text { Question: Using the options given below, evaluate the degree of relevance, within the com- } \\
\text { pany, of the environmental regulations/legislation for each of the following variables: }\end{array}$ \\
\hline$\frac{+\pi}{d}$ & Var01 & On the acquisition of technology to control pollution at the end of the production process. \\
\hline 产 & Var02 & $\begin{array}{l}\text { On increased costs as a result of fiscal and/or administrative sanctions due to responsibil- } \\
\text { ity for environmental damage, posing a threat to the growth of the business. }\end{array}$ \\
\hline
\end{tabular}

\begin{tabular}{|c|c|c|}
\hline 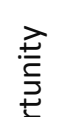 & Var03 & $\begin{array}{l}\text { On the development or acquisition of new products/processes/innovative technologies } \\
\text { to prevent pollution, involving ongoing learning and the development of organizational } \\
\text { capabilities. }\end{array}$ \\
\hline & Var04 & $\begin{array}{l}\text { Regulation serves as a guideline for the company to innovate, learn and change its prac- } \\
\text { tices, with this pressure being viewed as an opportunity to improve productivity and } \\
\text { competitiveness. }\end{array}$ \\
\hline
\end{tabular}
Source: prepared by the authors based on the literature.

The "use of environmental incentives and incentives for innovation" construct checked whether the companies under study had ever been offered an incentive, as shown in Table 2. In this case, the respondent had to mark the options concerning the situation of the company, with five possible responses on a five-point scale with a neutral position.

Table 2: Variables used to measure the use of environmental incentives and incentives for innovation construct

\begin{tabular}{c|l}
\hline Variable & $\begin{array}{l}\text { Question: Using the options below, evaluate the degree of relevance of each of them regarding } \\
\text { resources that have been obtained by the company for environmental issues and innovation: }\end{array}$ \\
\hline Var05 & Government subsidies (non-refundable). \\
Var06 & Government credits with special deadlines and below market interest (refundable). \\
Var07 & Government support for the use of risk capital. \\
Var08 & Tax benefits for innovation and/or ecological products \\
Var09 & International financing in financing funds from international financing and agents. \\
\hline
\end{tabular}
Source: prepared by the authors based on the literature.

The "effect on reputation" construct was measured using the question shown in Table 3 , in which respondents were asked to evaluate the relevance of some factors that could affect how the organization defined its eco-innovation strategies. This question was formulated with six variables, using a five-point scale with a neutral position.

Table 3: Variables used to measure the Effect on reputation construct

\begin{tabular}{|c|c|}
\hline Variable & $\begin{array}{l}\text { Question: Using the options below, evaluate the degree of relevance of each of the factors/ } \\
\text { agents on the actions of the company to improve its image concerning environmental issues: }\end{array}$ \\
\hline Var10 & Relationships with the supply chain (suppliers). \\
\hline Var11 & Conscious consumers, industrial clients and public clients. \\
\hline Var12 & $\begin{array}{l}\text { Relationships with environmental NGOs, business associations, media or participation in } \\
\text { movements for a better environment or the environmental awareness of society }\end{array}$ \\
\hline Var13 & Environmental performance of competitors. \\
\hline Var14 & Demands from investors to maintain profitability. \\
\hline Var15 & Image of greater environmental awareness among company employees. \\
\hline
\end{tabular}


The "support from upper management" construct was measured by the question in Table 4, asking respondents to assess the degree of relevance of the upper management when defining eco-innovation strategies. The question was formed with four variables, using a fivepoint scale and a neutral position.

Table 4: Variables used to measure the support from the upper management construct

\begin{tabular}{c|l}
\hline Variable & $\begin{array}{l}\text { Question: Using the options below, evaluate the degree of relevance of the upper manage- } \\
\text { ment in the definition of the following variables: }\end{array}$ \\
\hline Var16 & $\begin{array}{l}\text { The upper management in this organization informs people that it is essential to handle } \\
\text { environmental issues and create environmental programs and policies. }\end{array}$ \\
$\operatorname{Var} 17$ & $\begin{array}{l}\text { The company leaders have a policy that rewards employees for environmental improvements. } \\
\text { Var18 }\end{array}$ \\
Oar19 & $\begin{array}{l}\text { Organizational resources are earmarked for environmental initiatives. } \\
\text { The company leaders view the environment as highly strategic. }\end{array}$ \\
\hline
\end{tabular}
Source: prepared by the authors based on the literature.

The "technological competence" construct was measured by the question shown in Table 5, which required respondents to assess to what extent the organization is willing to conduct R\&D. The question contained four variables with a five-point Likert scale.

Table 5: Variables used to measure the technological competence construct

\begin{tabular}{c|l}
\hline Variable & $\begin{array}{l}\text { Question: Using the options below, evaluate to what extent the company could be charac- } \\
\text { terized by the following descriptions: }\end{array}$ \\
\hline Var20 & $\begin{array}{l}\text { The company is seen as the first to introduce new technologies and new products into the } \\
\text { sector. }\end{array}$ \\
Var21 & $\begin{array}{l}\text { The company has human resources for the development of eco-innovations. } \\
\text { Var22 }\end{array}$ \\
The company has the facilities and ability to adapt in order to adopt new environmental \\
technologies.
\end{tabular}
Source: prepared by the authors based on the literature.

The "environmental formalization" construct was measured by the question shown in Table 6, with the respondents being asked to evaluate to what extent the environmental management of the organization is formalized. The question was formed with five variables, using a five-point Likert scale.

Table 6: Variables used to measure the environmental formalization construct

\begin{tabular}{|c|c|}
\hline Variable & $\begin{array}{l}\text { Question: Using the options below, evaluate to what extent the environmental manage- } \\
\text { ment of your organization is formalized: }\end{array}$ \\
\hline Var24 & The environmental policy of the company is clearly documented in the corporate mission. \\
\hline Var25 & The company administration has a specific position/sector for environmental matters. \\
\hline Var26 & The company commercializes products with an ecological brand using environmental labeling. \\
\hline Var27 & $\begin{array}{l}\text { The company has an environmental management certification system using the ISO } 14000 \\
\text { standard and/or the FSC (Forest Stewardship Council) and/or Total Quality Environmental } \\
\text { Management (TQEM). }\end{array}$ \\
\hline Var28 & The company has implemented some form of environmental management system. \\
\hline
\end{tabular}
Source: prepared by the authors based on the literature. 
Operationally, in this study the extent of the development of "eco-innovation strategies" was determined using thirteen variables, as shown in Table 7, with a five-point Likert scale. The mean of the first five variables made up the construct of the "reactive strategies" and the mean of the other eight variables made up the construct of the "proactive strategies".

Table 7: Variables used to measure the eco-innovation strategies construct

\begin{tabular}{c|l}
$\begin{array}{c}\text { Constructs/ } \\
\text { Variable }\end{array}$ & $\begin{array}{l}\text { Question: Using the options below, evaluate the extent of the development of environ- } \\
\text { mental activities in your company: }\end{array}$ \\
Var29 & $\begin{array}{l}\text { The company is only concerned with pollution towards the end of the productive pro- } \\
\text { cess and uses remediation technology, such as the decontamination of degraded soil. } \\
\text { The company only acquires end of pipe technologies to control pollution for the purpos- } \\
\text { es of dealing with pollution before it enters the environment, such as effluent treatment } \\
\text { plants, cyclones, electrostatic precipitators, filters, incinerators, etc. }\end{array}$ \\
The company invests in environmental technologies and actions only to comply with \\
environmental legislation.
\end{tabular}
Source: prepared by the authors based on the literature.

In addition to these variables and constructs, to analyze the position of companies in the production chain of the sector, the "position in the production chain" construct was used. In the production chain of the cellulose, paper and paper products sector, different companies work in the various phases of the production cycle. For example, there are forest production companies, cellulose producers, companies that transform cellulose paste into rough paper and companies that produce paper artifacts (SOUZA, 2004).

To measure this construct, an objective question was asked, requiring the respondent to check one or more options regarding the situation of the company and how it is classified according to the CNAE 2.0 no 17 (National Classification of Economic Activities), published by the National Classification Committee [CONCLA] (2016). The classification is made up of subdivisions ranging from 17.1 to 17.4 , which are described in Table 8. 
Table 8: Variables used to measure the position in the production chain construct

\begin{tabular}{cl}
\hline Variable & $\begin{array}{l}\text { Question: In the production chain of the cellulose, paper and paper products sector, your } \\
\text { company is classified as a: }\end{array}$ \\
\hline Var42 & Manufacturer of cellulose and other pastes for making paper. \\
\hline Var43 & Manufacturer of paper, cardboard and cardstock. \\
\hline Var44 & Manufacturer of paper, cardboard, cardstock and corrugated paper packaging. \\
\hline Var45 & Manufacturer of paper, cardboard, cardstock and corrugated paper products. \\
\hline
\end{tabular}

Source: based on CONCLA (2016).

With the hypotheses and constructs defined, the theoretical model of the study was constructed based on the study of Maçaneiro and Cunha (2014) and can be seen in Figure 1.

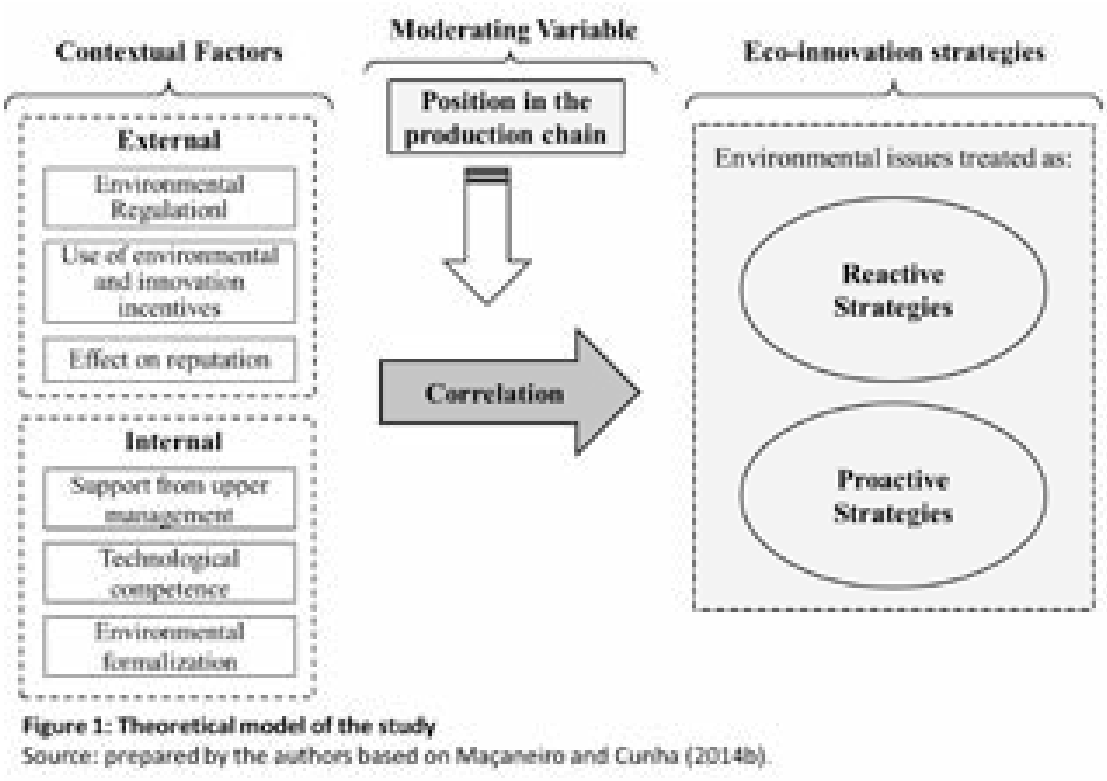

This model assumes that there is a relationship between the internal and external contextual factors and how eco-innovation strategies of organizations are defined, and these factors are affected by the variable for position in the production chain of the sector.

\section{RESULTS AND DISCUSSION}

This section begins with the characterization of the sample and its representativeness, followed by the validation, data cleansing and evaluation of the reliability of the scales. The latter subtitle provides details on the parameters for analyzing the correlations and the relationship that formed the hypothesis of the study.

\subsection{Representativeness and Characterization of the sample}

The representativeness of the sample was analyzed in the Brazilian regional context regarding the participation of the companies in the PIA-Empresa (Annual Industrial Research) of the IBGE (2010). For this purpose, the chi-square goodness of fit test was used to verify whether 
the rate of the sample for each Brazilian state matches its population. This test enabled an evaluation of the sample of 117 companies regarding the composition of companies for each region of Brazil, as shown in Table 9.

The PIA had a total of 3,147 companies, meaning that the result was as expected, as shown in the third column of Table 9, following the chi-square test. Therefore, it was possible to compare the number of companies in the sample in the different regions of the country and conclude that the sample is representative for each region, as a significance level of 0.159 was obtained (greater than 0.05), indicating that there is no significant statistical difference (HAIR et al., 2005).

Table 9: Chi square test to compare the representativeness of the sample of companies with that of the PIA: data for each region of the country

\begin{tabular}{c|c|c|c|c}
\hline \multirow{2}{*}{ Region } & \multicolumn{2}{c|}{ Companies listed in the PIA } & $\begin{array}{c}\text { Number of compa- } \\
\text { nies in the sample }\end{array}$ & Residual \\
\cline { 2 - 4 } & Number listed & Number expected & 70 & 2.0 \\
\hline Southeast & 1828 & 68.0 & 39 & 6.2 \\
South & 881 & 32.8 & 4 & -6.8 \\
Northeast & 291 & 10.8 & 2 & 0.4 \\
North & 42 & 1.6 & 2 & -1.9 \\
Central west & 105 & 3.9 & 117 & \\
\hline \multicolumn{2}{r}{ TOTAL } & 3147 & & 0.159 \\
\hline
\end{tabular}

Source: based on the IBGE (2010) and field research data (2012).

Concerning the size of the companies, a significant number are medium sized (45\%), in accordance with the Brazilian Service in Support of Small Businesses and Micro-enterprises (SEBRAE, 2016). Another significant portion of the sample is considered small (34\%). Large companies make up an important $17 \%$ of the sample and $4 \%$ of the companies are micro-enterprises. Furthermore, the sample can be characterized in other ways: the vast majority (97\%) is of Brazilian origin, including those with exclusively Brazilian controlling capital (80\%); the companies have existed on average for 36 years; most of them operate mainly in the Brazilian market (63\%). The respondents mostly occupy managerial positions or are directors (66\%) and, on average, have worked for the company for approximately ten years.

Regarding the position of the companies in the production chain, the numbers and groups can be seen in Table 10. It is worth mentioning that for this question the respondents were allowed to check more than one response, according to how their companies fit into the chain for their sector. For this reason, there are more answers than respondents because some operate in more than one stage of the production chain.

Table 10: Responding companies in the groups of the sector for cellulose, paper and paper products

\begin{tabular}{c|l|cc}
\hline Code & \multicolumn{1}{c}{ Description of the group } & $\begin{array}{c}\text { Total number of re- } \\
\text { spondents }\end{array}$ \\
\hline 17.1 & Manufacturer of cellulose and other pastes for making paper & $11 \%$ \\
17.2 & Manufacturer of paper, cardboard and cardstock & 41 & $29 \%$ \\
17.3 & $\begin{array}{l}\text { Manufacturer of paper, cardboard, cardstock and corrugated paper } \\
\text { packaging }\end{array}$ & 39 & $27 \%$ \\
17.4 & $\begin{array}{l}\text { Manufacturer of diverse paper, cardboard, cardstock and corrugated } \\
\text { paper products }\end{array}$ & 48 & $33 \%$ \\
\hline
\end{tabular}

Source: Field research data (2012) and the IBGE (2010).

a Number of companies taking multiple responses into consideration. 
According to the data in Table 10, the participation of the respondents in the groups of the sector was equitable in all groups. In other words, similar numbers of companies from groups $17.2,17.3$ and 17.4 participated, while 17.1 had the lowest number, possibly because of the total number of companies from this group was also smaller.

\subsection{Validation, Data Cleansing and Evaluation of the Reliability of the Scales}

Prior to the analysis of the hypothesis, the data were validated and cleansed by analyzing each variable using a box plot graph. No outliers were detected among the responses, nor were there any missing values, since the system that was used (Qualtrics ${ }^{\circledR}$ ) does not allow respondents to leave questions blank. However, some questionnaires were incomplete and were excluded from the study, leaving a total of 117 valid questionnaires.

Moreover, the reliability of the scales was verified, measuring "the extent to which a scale produces consistent results when repeated measurements are made of the characteristic" (MALHOTRA, 2006, p. 275). This evaluation was made by the internal consistency indicator Cronbach's Alpha, which indicates the mean correlation of all the attributes that make up the scales. The parameters for an acceptable level of reliability are shown in Table 11.

Table 11: Practical Rules for the Dimension of the Cronbach's Alpha Coefficient*

\begin{tabular}{|c|c|}
\hline Alpha coefficient variation ${ }^{*}$ & Intensity of variation \\
\hline$<0.6$ & Low \\
\hline $0.6 a<0.7$ & Moderate \\
\hline $0.7 a<0.8$ & Good \\
\hline $0.8 a<0.9$ & Very good \\
\hline 0.9 & Excellent \\
\hline
\end{tabular}

Source: Hair et al. (2005, p. 200).

* If Alpha $>0.95$, the items should be inspected to ensure that they measure different aspects of the concept.

Cronbach's Alpha was used for all the constructs in this study to verify their internal consistency, i.e., the extent to which the items that make up the scales are integrated. This is because the constructs were created from the theoretical framework, used in this study, as no previously validated scales were found in other studies. The results are summarized in Table 12.

None of the values of the Cronbach's Alpha was under 0.7, which is considered a good level of reliability of scales. On the contrary, most of the constructs had a very good intensity of variation, especially the "use of environmental incentives and incentives for innovation" and "proactive innovation strategies" constructs, which had excellent levels of reliability, in accordance with the parameters of Hair et al. (2005). Therefore, with these values, the constructs were shown to be adequate for the dimensions of the scales, suggesting that they were reliable. 
Table 12: Reliability of the Scales of the Constructs

\begin{tabular}{c|cc}
\hline Constructs & No. of variables & Cronbach's Alpha \\
\hline Environmental regulation & 4 & 0.821 \\
Use of environmental incentives and incentives for & 5 & 0.932 \\
innovation & 6 & 0.862 \\
Effect on reputation & 4 & 0.867 \\
Support from upper management & 4 & 0.784 \\
Environmental formalization & 5 & 0.878 \\
Reactive eco-innovation strategies & 5 & 0.716 \\
Proactive eco-innovation strategies & 8 & 0.903
\end{tabular}

Source: Field research data (2012).

\subsection{Analysis of the study hypothesis}

This analysis was based on the inferential statistics, using the test of the hypothesis, which can define it as accepted or refuted based on the data collected for the study. For this purpose, the Pearson correlation coefficient was used. This provides a numerical synthesis of the direction and intensity of the relationship between two variables, where high coefficients indicate high covariance and a strong relationship (FIELD, 2009). Parameters for the size of the coefficient (effect size) are shown in Table 13.

Table 13: Size of the effect of the correlation coefficient

\begin{tabular}{cc}
\hline Variation of the coefficient & Effect \\
\hline$r=0$ & No effect \\
$r= \pm 0,10$ & Small effect \\
$r= \pm 0,30$ & Medium effect \\
$r= \pm 0,50$ & Large effect \\
$r=1$ & Perfect effect \\
\hline
\end{tabular}

Source: Based on Field (2009).

The study hypothesis was analyzed by examining the position of the companies under study, with the companies being divided into two groups:

a. Group 1-manufacturers of cellulose and other pastes, paper, cardstock and cardboard (beginning of the production chain), companies classified as codes 17.1 and 17.2 by the CNAE, made up of 42 companies;

b. Group 2-manufacturers of a range of packaging and products made of paper, cardstock, cardboard and corrugated paper (end of the production chain), companies classified as codes 17.3 and 17.4 of the cellulose, paper and paper products sector, made up of 75 companies.

According to Souza (2004), companies that produce paper packaging and artifacts are those that produce the final products for consumers. These products include envelopes, cardboard boxes, toilet paper, writing paper and paper bags. The companies were divided into these groups for the purposes of this analysis. With these parameters having been established, the testing of the correlation of the constructs and their variables was conducted using the Pearson correlation coefficient. The scores are shown in Table 14. 
Table 14: Correlation between Contextual Factors and Eco-innovation Strategies with the influence of the moderating variable "Position in the production chain" - Group 1 (beginning of the production chain) and Group 2 (end of the production chain)

\begin{tabular}{|c|c|c|c|c|c|c|c|c|}
\hline \multirow[b]{2}{*}{$\begin{array}{c}\text { Constructs of contextual fac- } \\
\text { tors }\end{array}$} & \multicolumn{4}{|c|}{$\begin{array}{l}\text { Impact of position in the produc- } \\
\text { tion chain - Group } 1(\mathrm{~N}=42)\end{array}$} & \multicolumn{4}{|c|}{$\begin{array}{l}\text { Impact of position in the produc- } \\
\text { tion chain - Group } 2(\mathrm{~N}=75)\end{array}$} \\
\hline & \multicolumn{2}{|c|}{$\begin{array}{l}\text { Reactive Strat- } \\
\text { egies } \\
\text { r value p value }\end{array}$} & \multicolumn{2}{|c|}{$\begin{array}{l}\text { Proactive Strat- } \\
\text { egies } \\
\text { r value } p \text { value }\end{array}$} & \multicolumn{2}{|c|}{$\begin{array}{l}\text { Reactive Strat- } \\
\text { egies } \\
\text { r value p value }\end{array}$} & \multicolumn{2}{|c|}{$\begin{array}{c}\text { Proactive Strat- } \\
\text { egies } \\
\text { r value } p \text { value }\end{array}$} \\
\hline Envir & -0.614 & $0.000^{*}$ & 0.607 & $0.000^{*}$ & -0.203 & 0.080 & 0.211 & 0.070 \\
\hline $\begin{array}{r}\text { Use of environme } \\
\text { tives and incentiv } \\
\text { vation }\end{array}$ & -0.458 & $0.002^{*}$ & 0.373 & $0.015^{*}$ & -0.007 & 0.951 & 0.408 & $0.000^{*}$ \\
\hline Effect on reputation & -0.651 & $0.000^{*}$ & & $0.000^{*}$ & -0.190 & 0.102 & 0.365 & $0.001^{*}$ \\
\hline $\begin{array}{c}\text { Support from upper manage- } \\
\text { ment }\end{array}$ & -0.665 & $0.000^{*}$ & 0.684 & $0.000^{*}$ & -0.451 & $0.000^{*}$ & 0.615 & $0.000^{*}$ \\
\hline Technological competence & -0.533 & $0.000^{*}$ & 0.654 & $0.000^{*}$ & -0.266 & $0.021^{*}$ & 0.648 & $0.000^{*}$ \\
\hline Environmental formalization & -0.463 & $0.002^{*}$ & 0.782 & $0.000^{*}$ & -0.303 & $0.008^{*}$ & 0.720 & $0.000^{*}$ \\
\hline
\end{tabular}

Source: Field research data (2012).

$*$ p value $<0.05$

The data in Table 14 show that, in general, the correlation between contextual factors and proactive eco-innovation strategies was stronger in Group 1 (the companies at the beginning of the production chain) than in Group 2. Furthermore, it is interesting to note that the companies at the beginning of the production chain have a negative association with reactive strategies and a positive association with proactive strategies. Meanwhile, those at the end of the production chain showed no significant evidence in relation to reactive strategies. It should be emphasized that both groups showed negative relationships with reactive strategies.

As can be seen in Table 14, the correlation for the relationship between "environmental regulation" and eco-innovation strategies was much stronger for the companies at the beginning of the production chain, both positively for proactive strategies and negatively for reactive strategies, shifting from a medium to a large effect. The opposite was true for the companies at the end of the production chain. This finding can be justified by what Souza (2004) claimed, that companies at the beginning of the production chain in this sector have a reputation for being polluting companies and are the main focus of environmental regulations. This factor could also be taken into account in all the other analyses of the hypothesis.

For the correlation of the "use of environmental incentives and incentives for innovation" construct, there was almost no change in the intensity between the groups in terms of proactive strategies, but this was the only construct that saw a small improvement for Group 2. However, the companies at the beginning of the production chain had a stronger negative relationship with reactive strategies.

For the "effect on reputation" construct, there was a significantly stronger association for the companies at the beginning of the production chain and a drop in the score for companies at the end. This result is the opposite of the results reported by Menguc, Auh, and Ozanne (2010) and Carrillo-Hermosilla, Gonzalez, and Könnölä (2009), which claim that companies at the end of the production chain are more likely to bow to the pressure of environmentally conscious consumers. These authors state that these companies tend to consider their reputation as an important factor when it comes to defining strategies.

There was no significant change in the strength of the correlation for the relationship between "support from the upper management" and eco-innovation strategies regarding posi- 
tion in the production chain, although the companies in Group 1 had a better association.

The "technological competence" construct also saw no substantial change in the scores regarding the moderating variable, except that the companies at the beginning of the chain saw a more intense negative relationship with reactive strategies. The result for this construct differs from that of the study of Souza (2004), which found that companies at the end of the chain had greater technological competence in the cellulose, paper and paper products sector. The author mentions that their innovation could lead to the development of more environmentally friendly solutions for their businesses.

There was also no significant change in the strength of the correlation for the "environmental formalization" construct, which is not in agreement with the study of Buysse and Verbeke (2003). These authors found that the companies at the end of the production chain tend to have greater environmental formalization than the others in their sector, due to their having closer contact with the consumers of end products.

Therefore, the hypothesis of the study can be considered as rejected, in light of the sample data, for the Brazilian cellulose, paper and paper products sector. Thus, this result does not corroborate the findings of Buysse and Verbeke (2003), Carrillo-Hermosilla, Gonzalez, and Könnölä (2009), Menguc, Auh, and Ozanne (2010) and Souza (2004).

In addition to these correlation analyses, the $t$ test for independent samples was conducted to evaluate the statistical significance of the difference between the means of these two groups for the contextual factors. In other words, it was used to check for the existence of a difference between the means of the companies at the beginning of the production chain and the end. The $t$ test is a statistical technique used to evaluate differences between two population means (HAIR et al., 2005). The results are shown in Table 15.

Table 15: Test of the difference between the means for the contextual factors of the companies in Group 1 (beginning of the production chain) and Group 2 (end of the production chain)

\begin{tabular}{c|c|c|c|c}
\hline Constructs of Contextual Factors & $\begin{array}{c}\text { Mean Group 1 } \\
(\mathrm{N}=42)\end{array}$ & $\begin{array}{c}\text { Mean Group 2 } \\
(\mathrm{N}=75)\end{array}$ & t value & p value \\
\hline $\begin{array}{c}\text { Environmental regulation } \\
\text { Use of environmental incentives and } \\
\text { incentives for innovation }\end{array}$ & 3.64 & 3.41 & 1.281 & 0.203 \\
$\quad$ Effect on reputation & 3.16 & 1.66 & 2.554 & $0.013^{*}$ \\
Support from high administration & 3.40 & 3.06 & 1.928 & 0.056 \\
Technological competence & 3.40 & 2.72 & 2.438 & $0.016^{*}$ \\
Environmental formalization & 3.70 & 2.99 & 2.592 & $0.011^{*}$ \\
\hline
\end{tabular}

Source: Field research data (2012).

$* p$ value $<0.05$

The $t$ test showed that there was no significant difference only in the means of the "environmental regulation" and "effect on reputation" constructs, but in the latter construct can be considered this difference, since the $p$ value was close to the limit 0.05 . In relation to means, what should occur, according to the literature (BUYSSE; VERBEKE, 2003; CARRILLO-HERMOSILLA; GONZALEZ; KÖNNÖLÄ, 2009; MENGUC; AUH; OZANNE, 2010), is that the means for Group 2 (companies at the end of the production chain) should be higher than those of Group 1 (companies at the beginning of the production chain). Once again, this was not the case of the data in this study. All the means for Group 1 are higher or equal, according to the t test. This is not in agreement with the claim that companies at the end of the production chain make a greater impact in terms of environmental actions. 
For a better understanding of these results, some profile data of the companies of each group can be analyzed. Regarding size, the companies are made up of:

a. Group $1-24 \%$ are small companies and micro-enterprises, $52 \%$ are medium sized companies and $24 \%$ are large companies; and

b. Group $2-47 \%$ are small companies and micro-enterprises, $40 \%$ are medium sized and $13 \%$ are large companies.

In other words, Group 1 has a higher number of medium sized and large companies than Group 2, which may have influenced the correlations and resulted in the better means for the companies at the beginning of the production chain.

Another variable that may have had an influence is the market in which the companies operate:

a. Group 1-12\% operate in the local market and in their own state, $62 \%$ in the national market and $26 \%$ in the international market; and

b. Group $2-27 \%$ operate in the local market and in their own state, $64 \%$ in the national market and $9 \%$ in the international market.

Therefore, the companies at the beginning of the production chain are more active in the international market than those at the end. This could also have influenced these companies and made them more proactive concerning environmental issues.

\section{CONCLUSIONS}

The tests of the hypothesis were conducted to engage to what extent companies in the production chain of the sector focus on the relationship between contextual factors and the definition of their eco-innovation strategies. More specifically, the tests were conducted to map internal and external organizational factors that affect eco-innovation management, assessing changes in this relationship due to the position of companies in the production chain. The organizations under study belong to the cellulose, paper and paper products sector, and the sample included 117 companies.

In general, the companies in the sample show that the correlation with proactive innovation strategies was especially strengthened for those at the beginning of the production chain, with an increase in the mean for this group. On the other hand, the companies at the end of the production chain saw a drop in the strength of their associations and their means. Therefore, this result rejects the findings in the literature regarding sample data for the Brazilian cellulose, paper and paper products sector, which have shown that companies at the end of the production chain make a greater impact when it comes to environmental friendly actions as they have closer contacts with the consumers of the end products.

For the companies in the sample, the relationship between environmental regulation and eco-innovation strategy had a much stronger association at the beginning of the production chain, with the effect shifting from medium to large. This is in accordance with the literature, which states that these companies are the main focus of environmental legislation. They also saw a significant increase in the strength of their association with the effect on reputation and proactive innovation strategies, while the companies at the end of the chain saw their scores drop. 
This is not in agreement with the findings in the literature. The correlation of the companies for the environmental formalization construct regarding eco-innovation strategies is practically the same for companies at both ends of the production chain. This refutes the findings in the literature. This improved performance for companies at the beginning of the production chain could be explained by the fact that these are the most polluting companies and have become the focus of environmental legislation. Another explanation for this is that companies at the beginning of the chain are, on average, larger companies (large and medium sized) and operate in the international market. Therefore, these results are influenced by the characteristics of the industry sector.

With these results, this study contributes knowledge to the field of eco-innovation strategies through the definition of its constructs and the tests of the hypothesis. The work is original in that it is a study that was especially conceived and applied empirically, providing information on eco-innovation management, conductors and effects, enabling in-depth analyses, which are considered gaps in the literature. Therefore, this study contributes to the field in terms of the existing theory and the management of eco-innovation in organizations. It can serve as a guide for the innovative focus of environmental management in industries in the sector in question and other sectors, and can also aid further research in the field.

Finally, it is important to point out the limitations of the study in relation to surveys with sampling. In these cases, it is rarely possible to determine the degree of accuracy of the findings. Furthermore, the fact that the questionnaires were completed by only one person at each company, with no monitoring of their intentions or how they approached the questions before responding is another point to be considered. However, to ensure validity and reliability, the content was validated and the questionnaire was pre-tested, along with other precautions concerning the adopted methodology.

\section{ACKNOWLEDGEMENT}

The authors thank the support of the Universidade Estadual do Centro-Oeste - UNICEN$T R O$, as well as the financial support of the Coordenação de Aperfeiçoamento de Pessoal de Nível Superior (CAPES) and the Fundação Araucária to carry out this research.

\section{REFERENCES}

ANSANELLI, S. L. M. Mudança institucional, política ambiental e inovação tecnológica: caminho para o desenvolvimento econômico sustentável? ENCONTRO NACIONAL DE ECONOMIA POLÍTICA, Florianópolis, 8, 2003.

ARUNDEL, A.; KEMP, R. Measuring eco-innovation. Working Paper Series no 2009-017. United Nations University - Maastricht Economic and social Research and Training Center on Innovation and Technology, Maastricht, Netherlands, 2009. Disponível em: <file:///C:/Users/Usuario/ Downloads/wp2009-017\%20(1).pdf> Acesso em: 20 dez. 2018.

ARUNDEL, A.; KEMP, R.; PARTO, S. Indicators for environmental innovation: what and how to measure. In ANNANDALE, D.; PHILLIMORE, J.; MARINOVA, D. (eds.). International Handbook on Environment and Technology Management. Cheltenham: Edward Elgar, 2003. p. 324-339.

ASHFORD, N. A. Pathways to sustainability: evolution or revolution? In GEENHUIZEN, M.; GIBSON, D. V.; HEITOR, M. V. (eds.). Regional development and conditions for innovation in the network 
society. International series on technology policy and innovation. Ohio: Purdue University Press, 2005. p. 35-59. Disponível em: <http://dspace.mit.edu/bitstream/handle/1721.1/1588/Delft. pdf?sequence=2> Acesso em: 19 dez. 2018.

BARBIERI, J. C. Gestão ambiental empresarial: conceitos, modelos e instrumentos. 3. ed. São Paulo: Saraiva, 2011.

BLACKBURN, W. R. The sustainability handbook. Washington: Environmental Law Institute, 2008.

BRASIL. Lei n. 6.938, de 31 de agosto de 1981. Dispõe sobre a Política Nacional do Meio Ambiente, seus fins e mecanismos de formulação e aplicação. Disponível em: <https://www.planalto.gov. br/ccivil_03/leis/16938.htm> Acesso em: 20 dez. 2018.

BUYSSE, K.; VERBEKE, A. Proactive environmental strategies: a stakeholder management perspective. Strategic Management Journal, v. 24, n. 5, p. 453-470, 2003. Disponível em: <https:// onlinelibrary.wiley.com/doi/abs/10.1002/smj.299> Acesso em: 21 dez. 2018.

CARRILLO-HERMOSILLA, J.; GONZÁLEZ, P. D. R.; KÖNNÖLÄ, T. Barriers to eco-innovation. In CARRILLO-HERMOSILLA, J.; GONZÁLEZ, P. D. R.; KÖNNÖLÄ, T. (eds.). Eco-innovation: when sustainability and competitiveness shake hands. New York: Palgrave Macmillan, 2009. p. 28-50.

CASSIOLATO, J. E.; LASTRES, H. M. M. Sistemas de inovação: políticas e perspectivas. Parcerias Estratégicas, v. 8, p. 237-255, maio 2000. Disponível em: <http://dx.doi.org/10.1590/S0102$88392005000100003>$ Acesso em: 20 dez. 2018.

COHEN, W. M.; LEVINTHAL, D. A. Absorptive capacity: a new perspective on learning and innovation. Administrative Science Quarterly, v. 35, n. 1, p. 128-152, 1990. Disponível em: <http://www.wz.uw.edu.pl/pracownicyFiles/id14331-id12539-Cohen,\%20Levinthal\%20-\%20 Absorptive\%20capacity.pdf> Acesso em: 20 dez. 2018.

CONCLA - Comissão Nacional de Classificação. Pesquisa CNAE. 2016. Disponível em: <http:// www.cnae.ibge.gov.br/> Acesso em: 20 dez. 2018.

DONAIRE, D. Gestão ambiental na empresa. 2. ed. São Paulo: Atlas, 2007.

DOSI, G. Institutions and markets in a dynamic world. The Manchester School, v. 56, n. 2, 1988. Disponível em: <http://onlinelibrary.wiley.com/doi/10.1111/j.1467-9957.1988.tb01323.x/ abstract> Acesso em: 20 dez. 2018.

FIELD, A. Descobrindo a estatística usando o SPSS. 2. ed. Porto Alegre: Artmed, 2009.

FINEP - FINANCIADORA DE ESTUDOS E PROJETOS. Instrumentos de apoio: o que são. 2016. Disponível em: <http://www.finep.gov.br/apoio-e-financiamento-externa/instrumentos-deapoio/quais-sao-os-instrumentos-de-apoio> Acesso em: 20 dez. 2018.

HAIR JR., J. F.; BABIN, B.; MONEY, A. H.; SAMOUEL, P. Fundamentos de métodos de pesquisa em administração. Porto Alegre: Bookman, 2005.

HART, S. A natural-resource-based view of the firm. The Academy of Management Review, v. 20, n. 4, p. 986-1014, 1995. Disponível em: <http://dx.doi.org/10.2307/258963> Acesso em: 20 dez. 2018. 
INSTITUTO BRASILEIRO DE GEOGRAFIA E ESTATÍSTICA. Pesquisa Industrial - Empresa. 2010. Disponível em: <http://www.ibge.gov.br/home/estatistica/economia/industria/pia/ empresas/2010/defaulttabpdf.shtm> Acesso em: 20 dez. 2018.

Pesquisa Industrial de Inovação Tecnológica. 2011. Disponível em: <http://www.ibge.gov. br/home/estatistica/economia/industria/pintec/2011/default.shtm> Acesso em: 20 dez. 2018.

KANERVA, M.; ARUNDEL, A.; KEMP, R. Environmental innovation: using qualitative models to identify indicator for policy. United Nations University - UNU-MERIT, Working Papers Series, 2009. Disponível em: <http://digitalarchive.maastrichtuniversity.nl/fedora/get/guid:b26053089ff9-43fa-ba04-6ca42a852a5d/ASSET1> Acesso em: 20 dez. 2018.

KEMP, R.; ARUNDEL, A. Survey Indicators for Environmental Innovation. Oslo, IDEA Report, STEP Group, 1998. Disponível em: <https://brage.bibsys.no/xmlui/bitstream/handle/11250/226478/ Idea8.pdf?sequence=1> Acesso em: 20 dez. 2018.

KEMP, R.; FOXON, T. J. Typology of Eco-Innovation. In MEI project: measuring Eco-Innovation. European Commission, ago. 2007. Disponível em: <http://www.merit.unu.edu/MEl/deliverables/ MEI\%20D2\%20Typology\%20of\%20eco-innovation.pdf> Acesso em: 20 dez. 2018.

LUSTOSA, M. C. J. Inovação e tecnologia para uma economia verde: questões fundamentais. Política Ambiental. Economia verde: desafios e oportunidades, v. 8, p. 111-122, 2011. Disponível em: <http://www.ie.ufrj.br/images/gema/Gema_Artigos/2011/PoliticaAmbiental08portugues. pdf> Acesso em: 20 dez. 2018.

MAÇANEIRO, M. B.; CUNHA, S. K. da. Theoretical Analysis Model of the Adoption of Reactive and Proactive Eco-Innovation Strategies: the Influence of Contextual Factors Internal and External to Organizations. Brazilian Business Review, v. 11, n. 5, p. 1-23, 2014. Disponível em: <http://dx.doi. org/10.15728/bbr.2014.11.5.1> Acesso em: 20 dez. 2018.

MAÇANEIRO, M. B.; CUNHA S. K. da; BALBINOT, Z. Drivers of the adoption of eco-innovations in the pulp, paper, and paper products industry in Brazil. Latin American Business Review, v. 14, p. 179-208, 2013. Disponível em: <http://dx.doi.org/10.1080/10978526.2013.833465> Acesso em: 20 dez. 2018.

MALHOTRA, N. K. Pesquisa de marketing: uma orientação aplicada. 4. ed. Porto Alegre: Bookman, 2006.

MENGUC, B.; AUH, S.; OZANNE, L. The interactive effect of internal and external factors on a proactive environmental strategy and its influence on a firm's performance. Journal of Business Ethics, v. 94, p. 279-298, 2010. Disponível em: <http://dx.doi.org/10.1007/s10551-009-0264-0> Acesso em: 20 dez. 2018.

MILES, M. P.; COVIN, J. G. Environmental marketing: a source of reputational, competitive, and financial advantage. Journal of Business Ethics, v. 23, n. 3, p. 299-311, 2000. Disponível em: <http://dx.doi.org/10.1023/A:1006214509281> Acesso em: 20 dez. 2018.

NELSON, R. R.; WINTER, S. G. Uma teoria evolucionária da mudança econômica. Campinas: Ed. da Unicamp, 2005.

PORTER, M.; VAN DER LINDE, C. Toward a new conception of the environment-competitiveness 
relationship. Journal of Economic Perspective, v. 9, n. 4, p. 97-118, 1995. Disponível em: <http:// dx.doi.org/10.1257/jep.9.4.97> Acesso em: 20 dez. 2018.

RENNINGS, K. Towards a theory and policy of eco-innovation - neoclassical and (co-) evolutionary perspectives. Discussion Paper no 98-24. Centre for European Economic Research (ZEW), Mannheim, Germany, 1998. Disponível em: <ftp://ftp.zew.de/pub/zew-docs/dp/dp2498.pdf> Acesso em: 20 dez. 2018.

SCHUMPETER, J. A. Teoria do desenvolvimento econômico: uma investigação sobre lucros, capital, crédito, juros e o ciclo econômico. São Paulo: Abril Cultural, 1982.

SCHMIDHEINY, S. Mudando o rumo: uma perspectiva empresarial global sobre desenvolvimento e meio ambiente. Rio de Janeiro: Ed. da FGV, 1992.

SERVIÇO BRASILEIRO DE APOIO ÀS MICRO E PEQUENAS EMPRESAS. Critérios de classificação de empresas. 2016. Disponível em: <http://www.sebrae-sc.com.br/leis/default.asp?vcdtexto=4154> Acesso em: 20 dez. 2018.

SHARMA, S. Managerial interpretations and organizational context as predictors of corporate choice of environmental strategy. Academy of Management Journal, Briarcliff Manor, Academy of Management, v. 43, n. 4, p. 681-697, 2000. Disponível em: <https://www.jstor.org/ stable/1556361?seq=1\#page_scan_tab_contents> Acesso em: 20 dez. 2018.

SHARMA, S.; PABLO, A. L.; VREDENBURG, H. Corporate environmental responsiveness strategies: the importance of issue interpretation and organizational context. The Journal of Applied Behavioral Science, v. 35, n. 1, p. 87-108, 1999. Disponível em: <http://dx.doi. org/10.1177/0021886399351008> Acesso em: 20 dez. 2018.

SOUZA, R. S. de. Fatores de formação e desenvolvimento das estratégias ambientais nas empresas. Tese (Doutorado em Administração) - Universidade Federal do Rio Grande do Sul, Porto Alegre, RS, Brasil, 2004.

YOUNG, C. E. F.; PODCAMENI, M. G. B.; MAC-KNIGHT, V.; OLIVEIRA, A. S. Determinants of Environmental Innovation in the Brazilian Industry. CONGRESO DE LA ASOCIACIÓN LATINOAMERICANA Y DEL CARIBE DE ECONOMISTAS AMBIENTALES Y DE RECURSOS NATURALES, Heredia, UNA - Universidad Nacional Costa Rica, 4, 2009. Disponível em: <http://www.ie.ufrj.br/ gema/pdfs/DETERMINANTS\%20OF\%20ENVIRONMENTAL\%2OINNOVATION\%20IN\%20THE\%20 BRAZILIAN\%20INDUSTRY.pdf> Acesso em: 20 dez. 2018. 